\title{
Recombinant expression, purification and copper- binding characteristics of the amino terminus of a Plasmodium falciparum copper transport protein
}

\author{
David Choveaux*, JP Dean Goldring \\ From Parasite to Prevention: Advances in the understanding of malaria \\ Edinburgh, UK. 20-22 October 2010
}

Copper is an essential micronutrient for all living organisms since it is required as a catalytic cofactor for metabolic enzymes, such as cytochrome-c oxidase. In the higher eukaryotes copper is acquired by transport across the plasma membrane via the copper transport protein, Ctr1. The malaria parasite expresses copper requiring enzymes, such as S-adenosylhomocysteine hydrolase and cytochrome-c oxidase as well as copper chaperones, such as Cox17. How the parasite acquires copper has, however, not yet been described. In silico BLAST-P screening of the Plasmodium database (www.PlasmoDB. org), using a putative copper transport protein sequence from the related parasite Theileria parva, identified a candidate copper transport protein sequence for the malaria parasite. The sequence was present in the genome of human, monkey, avian and rodent infecting species of Plasmodium. Each sequence contained features typical of copper transport proteins such as copperbinding motifs in the $\mathrm{N}$-terminal region, three membrane spanning domains as well as the characteristic MxxxM and GxxxG motifs, located in the second and third transmembrane domains respectively. Two putative copper transport proteins are predicted to be present in the Plasmodium falciparum genome (PF14_0211 and PF14_0369). The predicted N-terminal domains for each protein were cloned and expressed as soluble $48 \mathrm{kD}$ (PF14_0211) and 54kD (PF14_0369) fusion partners with maltose-binding protein. Copper was shown to bind to the purified recombinant fusion proteins both in vivo and in vitro using the copper-specific bicinchoninic acid assay. For each protein an immunogenic peptide, within the $\mathrm{N}$-terminus, was selected, synthesised,

Department of Biochemistry, University of KwaZulu-Natal, Pietermaritzburg 3209, South Africa coupled to rabbit albumin carrier and used to raise antibodies in chickens. The antibodies were affinity purified and used to probe for malarial proteins. Copper is important for a range of enzyme activities in malaria parasites, which suggests that a malaria copper transport protein is an interesting target for novel anti-malarial compounds.

Published: 16 December 2010

doi:10.1186/1475-2875-9-S2-P62

Cite this article as: Choveaux and Goldring: Recombinant expression, purification and copper-binding characteristics of the amino terminus of a Plasmodium falciparum copper transport protein. Malaria Journal 2010 9(Suppl 2):P62.
Submit your next manuscript to BioMed Central and take full advantage of:

- Convenient online submission

- Thorough peer review

- No space constraints or color figure charges

- Immediate publication on acceptance

- Inclusion in PubMed, CAS, Scopus and Google Scholar

- Research which is freely available for redistribution
() Biomed Central 